\title{
Serine Protease HTRA1
}

National Cancer Institute

\section{Source}

National Cancer Institute. Serine Protease HTRA1. NCI Thesaurus. Code C101311.

Serine protease HTRA1 (480 aa, $51 \mathrm{kDa}$ ) is encoded by the human HTRA1 gene. This protein plays a role in the proteolysis of IGF-binding proteins. 